\title{
A Contrastive Analysis of Word Formation of English and Chinese Neologisms
}

\author{
Shiyun Cheng \\ Shanxi Normal University, China
}

\begin{abstract}
Neologisms refer to the words created to express new things, new concepts and new ideas in written and oral communication. Since the 1980 s, the world has entered into an information age. The world has witnessed great changes in political, economic, cultural field. At the same time, China has been carrying out a series of political and economic reforms, which have brought about amazing changes in all social aspects. As a result, a great deal of neologisms have appeared both in English and Chinese. There are three sources of neologisms both in English and Chinese: creating new words with native word elements, adding new meanings to existing words and borrowing new words from other languages. This paper focus on the first one of these three sources: word-formation, and analyzes the similarities and differences of three major ways of word-formation of neologisms in both English and Chinese: compounds, affixations, shortenings.
\end{abstract}

Index Terms—neologism, word formation, compounds, affixations, shortenings

\section{INTRODUCTION}

Language is a symbol system which acts as a kind of social communicative tool. It is composed of voice, vocabulary and grammar, "vocabulary is the most sensitive constitute of language"(Chenyuan, 2000, p.209). Neologisms are new words and expressions. There are different definitions about neologisms. Such as: Zhang Yongyan(1982, p.87) think that "At first, neologisms maybe are used by minority of people, but gradually more people are familiar with the things which the neologisms refer to, they will be used in a large scale." Fu Haiqing(1985, p.171) also pointed "Neologisms are created in order to adjust to society. Through the authenticate of practical usage, they are accepted by language." Language is a social phenomenon and changes with the development of society. Among the three language elements, pronunciation and grammar are relatively stable and vocabulary is sensitive to social changes. Since the 1970s, China has been implementing the policy of opening to the outside world and a series of reforms at home, which lead to great changes in all aspects of social life. Across the world, great changes have also taken place in political, economic and cultural fields. Neologisms are being invented or introduced every day to express new things and new ideas in society.

English has established itself as an international language, and more and more people in the world begin to learn English as a second language or foreign language. In order to communicate with people all over the world efficiently, Chinese English learners need to keep up with the latest vocabulary both in English and Chinese. English neologisms are a great challenge.

Although English and Chinese belong to different language families, they play the same social function, serving people's communication. Comparing English neologisms with Chinese ones helps us to know better both similarities and differences between them, which is of great significance for foreign language teaching and foreign language learning.

\section{ELEMENTS OF GENERATION OF NEOLOGISMS}

With the development of technology and society, people's life has changed a lot. Therefore, a large deal of neologisms appeared. The generation of neologisms is not only the result of language itself continuous development, but also the need which meet people's demand to express new things and new ideas.

\section{A. Development of Science Leads to the Generation of Neologisms}

Since the 1980s, scientific technology has been developing fast, which impulse the production of neologisms. Digital technology brings these words: digital audio broadcasting, digital compact cassette, digital compression, digital compact disc. With the popularization of computer technology, a series of relevant new words were accepted. For example: Internet, cyberspace, website, E-mail, e-commerce, multimedia, firewall, software, mouse, modem, explorer, home page, menu, file, hacker, virus, virus-killer, etc. Also the development of medical science and genetics stimulate the production of new words: test-tube baby, genetic code, DNA, clone, genetic engineering, keyhole surgery, paternity test, etc. In scientific field, some new words created for interdisciplinary subject, for example: chemical ecology, eco-geography, genetic engineering, geotechnical engineering, mechatronics, social ecology, space biology, bionics, etc.

\section{B. The Changes of Politics and Economy Arouse the Generation of Neologisms}

In recent years, political and economic situation all over the world have a great change, which attribute to the 
production of relevant new words. "Global strategic policy, collapse of Soviet Union, anti-Terrorism War, political pluralism, Multifold World, APEC, Clintonomics, Bushnomics, trade war, Euro, Euro-zone, Petrodollar, cyclic economy, bubble economy" are all typical examples.

Since the reform and opening-up policy, China has carred out a series of political and economic structural reform. Then, there are new words which are talked about by people. For example, market economy, joint ventures, solely-foreign-owned enterprises, privately-owned enterprises, contract responsibility system, One country-Two systems, annual salary, bull market, iron rice bowls, etc.

\section{Diversity of People's Life Impulses the Generation of Neologisms}

With the development of society, people' life becomes colorful and various. What happened as a result was that many new words appear in life. In present time, almost everyone use "mobile phone" to "call" or "text message" to communicate with each other who are not by their sides. They can also "send E-mail" to greet someone they miss or inform important information. If they want to buy something, they can go to "shopping mall" "supermarket" or even they needn't go outside but buy what they need "online". In order to keep slim and fit figure, they will do "yoga", "body building", "slimnasics", "aerobic dancing", "isometrics" "bikecise" and "step training", etc.

What was talked about above is just a simple and rough classification of elements of generation of neologisms. In fact, almost every day there are new words which we never heard before appear and will appear in the future with the development of world.

\section{Contrastive Analysis of Word Formation of Chinese And English NeOlogisms}

Although English and Chinese belong to different language family, the generation of their neologisms are almost same, which is produced by three ways: creating new words with native word elements - word formation, adding new meanings to existing words and borrowing words from other languages. Of these three ways, word formation is the most main and important way, which is consist of three main methods: compounding, affixation and shortening. Now, the writer will compare these three ways of neologisms between Chinese and English.

\section{A. Compounding}

Compounding is the way which combines at least two words into one word according to certain order. Words created by compounding are called compounds. Compounds can be divided into different types. According to word class, it can be divided into compound nouns, compound verbs, compound adjectives, etc. Among them, compound nouns have the largest proportion. According to inner structure, compounds can be divided into noun+noun, noun+verb, verb+verb, etc. According to semantic logical relationship of each constituent, compounds can be divided into the joint type, partial formal, subject-predicate type, predicate-object type, etc.

In English, there are more and more new words which just combined by putting two words together simply, which makes English new compounds looks more like expressions. For example, couch potato, chat room, best practice, call center, zero tolerance, web designer, global economy, etc.

Sometimes, two words combine into one single new compound. Such as: jobseeker, webpage, website, aftermarket, bankroller, etc.

Otherwise, some new compounds consisted of two words with a hyphen between them: virus-killer, baby-sit, bottom-down, Euro-zone, low-rent, post-modern.

More and more new words are consisted of three or more words, such as: video on demand, pull-down menu, predict and provide, personal electronic device, pay-as-you-go, meet-and-greet, home health aide, etc.

Chinese compounding ability is strong. Compounding is the most important way of creating modern Chinese new words. For example: 白领, 出炉, 冲浪, 上岗, 美体, 扶贫, 跳楼价, 地球村, 信用卡, 心理障碍, 新新人类, 知识产权, 工薪阶层, 调制解调器, etc.

Most of modern Chinese words are double syllable words, but in new words created at present, more and more multi-syllable words appear. Even there are many new words consisted of five words. This show a trend which multi-syllable new words become more and more frequent. Such as: 安乐死, 有机食品, 搬家公司, 博士后流动站, 菜篮子工程, 开放式基金, 网站管理员, 数字化电视, 豆腐渣工程, 技术密集型产业, 现代企业制度, 住房公 积金贷款，有中国特色的社会主义，卫星跟踪定位系统，高新技术开发区，etc.

From these examples, we can make a conclusion that both in English and Chinese, the structure of neologisms become more and more complex, which lead to the unclear confine between words and expressions.

\section{Grammaticality of English Compounds}

English compounds show certain syntactic relation. They are the simplified form of fixed phrase and sentence. Therefore, English emphasize the structure relation of linear combination, which means their constituents must be combined according to certain grammatical rule. Gremmaticality of English compounds lies on the grammatical relation of constituents of compounds (Chu Xiaoning, 2004).

The first one we talk about is subject-predicate relation. The relationship of two constituents is subject-predicate relation, which can form a subject-predicate sentence. For example: answering service - a commercial service that answers telephone calls for its clients, poverty stricken - Poverty strikes the place. In form, compounds of 
subject-predicate type are consisted of a noun and a verb. The meaning can be showed through recovering the relation of subject and predicate.

In addition, there are compounds that show other grammatical relation:

Predicate-object relation: assisted area - to assist the area, peace loving - to love peace.

Joint relation: consisted of two words which have same, resemble, relevant or opposite meanings. Such as: transmitter-receiver - transmitter and receiver, amplifier-inverter - amplifier and inverter.

Partial formal: the former root used as modifier to confine the latter root which is the main meaning of this compound: aftermarket - the market for products that people buy after they have bought another related product, airport fiction - books, especially ones that are not very serious, that people buy at airport to read while they are traveling on planes.

Therefore, the meaning of compounds can be gained by analyzing the relation of their constituents. We can get another finding from above examples: when consisting of compounds, the constituents may have changes in form. For example: "answer" in "answering service" is changed into "answering".

\section{Semantic feature of Chinese compounds}

$\mathrm{Xu}$ Tongqiang once pointed "The prominent feature of Chinese is semantic, however the Indo-European language is grammatical. So we can call Indo-European language grammatical language, and Chinese semantic language." (Xu Tongqiang, 1998, p.52). The constituents of Chinese compounds don't have grammatical relation internally, but have the lexical structural relation which combined with the conceptual meanings of two morphemes. (Liu Shuxin,1990). Now, we will talk about something of semantic feature of Chinese compounds.

The semantic feature of Chinese compounds is decided by the self-sufficiency of their basic components-Chinese characters. As fundamental components of Chinese compounds, Chinese character is not only phonetic unit, but also semantic unit.

Chinese compounds don't have any changes in form and don't have obvious word classification. For example, the same Chinese word can be used as both noun and verb sometimes.

Chinese compounds don't have obvious external morphological characteristics and evident classification of parts of speech. The combination of the two constitutes rely on semantic relation, but not grammatical relation. "The combination of compounds is of parataxis-prominence. The so-called parataxis means that there is no symbols of words form in the combination of compounds, which counts on the bonds of meanings." (Su Xinchun, 1994, p.26).

Chinese compounds based on the fundamental unit(key word) with the help of explanation and ornament of other word. Usually, the latter word represent the meaning genre, and the former word confines and modifies the latter word. Such as: 吧: 吧台, 吧女, 吧娘; 酒吧, 网吧, 水吧, 奶吧, 氧吧, 迪吧, 书吧.

\section{B. Affixation}

Language can be divided into isolating language, agglutinative language, inflectional language and polysynthetic language. Although there are some words in Chinese which show synthetic feature, in general, Chinese belong to isolating language. Contrast with Chinese, English is called synthetic language. The feature of synthetic language is that there are many affixes. Therefore, affixation plays an important role in creating new English words. Shao Zhihong pointed out that affixes in Chinese are closed, comparatively, affixes in English are open. With the development of society, some new affixes are created. (Shao Zhihong, 1997). In terms of Chinese and English, affixes in Chinese are not more abundant than that in English and the proportion of English affixations is about 30 percent to 40 percent. (Zhang Weiyou, 1997).

Affix can be divided into prefix, infix and suffix according to the place of word-forming affixes; it can also be divided into nominalizing affix, verbalizing affix, adjective affix and adverbial affix according grammatical function; otherwise, it can be divided into affix which individually express people, express verb and express property according to the semantic meaning of affixes, etc.

\section{Affixation in English compounds}

Affixation refers to the way that add an affix to a certain roots to create new words. Affixation is a traditional way to form new words in English, which not only enlarge the quantity of English words, but also enrich the expressive forms. In general, English affixes can be divided into prefix and suffix. Generally speaking, prefix only change the meaning of word, but not change the word class. For example, when "happy" was added with" un-", it becomes "unhappy", which change the meaning of it, but not change the class of word. Nevertheless, there are a little exceptions, for example: force-enforce, large-enlarge, rich-enrich. Suffix changes not only the meaning but also the class of a word. Here we take "invent" for an example. "Invent" is a verb, when add a suffix "-or" to it, it becomes "inventor", which changes into a noun and refers to the people who responsible for the verb "invent". In English, suffix can be divided into four types according to word class: nominal suffix, such as: -age, -hood, -ship, -ism, -er/or, -ee, -ment, -ist, -ation, -ity, -ness,etc; verbalizing suffix: -en, -fy, -ize, -ate, etc; adjective suffix: -y, -ish, -ful, -less, -like, -ive, -able, etc; adverbial suffix: -ly, -ward, -wise, etc.

In English, some traditional affixes still play an important role in creating new words. Such as, super: supercat, supersize, superstar, superdelegate, supergravity, superminicomputer, supermolecule, superstring; de-: delist, demerge, deindustrialization, deorbit, deplane, depowerment, deprofessionalization, derecongnize, deselect, destatization, etc. 
There are some affixation which gain new meaning in the process of creating neologisms. For example, "cyber-" means computer, but now have the meaning " use Internet": cybercafe, cybercrime, cyberforensics, cyberland.

Also some affixes are created in recent decades, such as, "-speak", which means a kind of speech style or a kind of language: netspeak, computerspeak, artspeak, sportspeak, college-speak, businessspeak; “-holic”, which means someone who have a certain preference: alcoholic, workholic, movieholic, teleholic, webholic, etc.

\section{Affixation in Chinese Compounds}

Lu Shuxiang(1979) thinks that there are not many typical affixes in Chinese. In Chinese, “阿, 第, 初, 老, etc” and “儿, 子, 头, 性, 者, 化, etc” are usual traditional prefixes and suffixes individually. These kind of traditional affixes have a strong ability of creating new words. For example, “性”: 一次性, 实质性, 伸缩性，技术性，预见性，可读性， 可行性, 可塑性, 趋同性, 政策性, etc. Some of these traditional affixes have changed the meaning in the process of creating neologisms, which means their usage become more active and extensive. Such as, “老”: 老外，老美，老广 (广东人), 老记 (记者), 老编(编辑), 老妈, 老姐, 老爸, etc.

Zhou Qiqiang(2001) pointed that since reform and openness, the popularity of analogical word formation weakens the meanings of some Chinese words, Chinese word formation present the tendency of new affixation, which have been called quasiaffix. For example: 出国热, 电脑热, 英语热, 地产热, 股票热, 旅游热, 足球热, 健美热, etc. The character “热” is in the certain place of these neologisms, which show that the class of this word is noun. Otherwise, “热” does not mean "hot" in these words, but means that something is very popular at certain period. So as following examples:

盲: 科盲, 法盲, 股盲, 电脑盲, 电影盲

反: 反腐败, 反恐, 反季节, 反弹反倾销, 反走私, 反文化

超：超编, 超值, 超负荷, 超短裙, 超一流, 超人, 超动感

软: 软件, 软广告, 软实力, 软科学, 软环境, 软包装, 软资源

族: 上班族, 追星族, 背包族, 单身族, 打工族, 有车一族

\section{Conclusion}

Comparatively, ability of affixation to create new words in Chinese is not as flexible as English. Characters in Chinese are all independent units, and the structure of Chinese character is closed, which means we can not increase or decrease the character components to create new words. However, to the contrary, we can add affixes to an English root to make a new word. In addition, the process of English word formation is more complex than Chinese. For example, "superlongleggedness" include prefix "super-", suffix "-ed" which show adjective property and suffix "-ness" which change the word class into noun. But, we must admit that tendency of affixation strengthen the ability of Chinese word formation.

\section{Shortening}

Shortening is another method used usually to create neologisms. Language is a important tool to communicate. Social communication demand us to express abundant contents with the most concise and simple way. Shortening is the best method to meet this requirement. For example, FBI is the abbreviation of Federal Bureau of Investigation, ADIS is the abbreviation of Acquired Immunodeficiency Syndrome, and OPEC is the abbreviation of Organization of Petroleum Exporting Countries. In Chinese, “浙大” is the abbreviation of “浙江大学”, “人代会” is the abbreviation of “人民代表 大会”, “入市” is the abbreviation of “进入世界贸易组织”. The quantity of Chinese abbreviation is not as much as English, but it will be enlarged with the development of scientific technology.

\section{Abbreviation in English Neologisms}

\subsection{Initialism}

Initialism is a way which picks up the first letter of each word in phrase to represent that phrase. There are some examples: BBS-bulletin board system, GPS-Global Positioning System, PDA-personal digital assistant, ADHD-attention deficit hyperactivity disorder, OCD-obsessive compulsive disorder, EU-European Union, AI-artificial intelligent, PC-personal computer.

\subsection{Acronym}

Acronym is a way we read the abbreviation which organized with the first letter of each word in phrase as a word. Such as: AIDS-acquired Immune Deficiency, ROM-read only memory, TOEFL-Test of English as a Foreign Language, CALL-computer-assisted language learning.

\subsection{Clipping}

Clipping refer to the way that clip the certain part of a original word. For example: cell-cellphone, dino-dinosaur, AD-advertisement, mini-miniskirt, expo-exposition, net-Internet, Info-information, script-prescription, pacifist-pacificist, daily-daily paper, pop-popular music, taxi- taximeter cab.

\subsection{Blending}

Blending means that we organize the certain part of each word of a compound into its abbreviation. Such as: modem-modulator + demodulator, Medicare-medical +care, infowar-information + war, autoindustry-automobile + industry.

\section{Abbreviation in Chinese Neologisms}

There are two types of abbreviation in Chinese neologisms: extraction and generalization with number. Extraction 
refer that key part or morpheme of original or phrase be elected to form new word. Such as: 超市-超级市场, 环保-环 境保护, 外交-外籍教师, 福彩-福利彩票, 大本-大学本科, 成教-成人教育, 私企-私营企业, 红股-红利股票, 危房-危险房屋, 影星-电影明星, 寿险-人寿保险, 空姐-空中小姐, 租金-租赁资金, 外长-外交部长, 通缩-通货 紧缩, 通胀-通货膨胀, 考研-参加研究生考试, 立交桥-立体交叉桥, 外企-外商投资企业奥申委-奥林匹克运动会 申办委员会.

The second abbreviation of Chinese neologisms is generalization with number. Such as: 三讲-讲学习, 讲政治, 讲 正气; 三个面向-面向现代化，面向世界，面向未来; 三资企业-中外合资企业，外商独资企业，中外合作企业; 四乱-乱收费, 乱罚款, 乱推派, 乱检查; 两个文明-物质文明和精神文明. Although this way have strong generality, can not express clear meaning and confined by time, field and place.

\section{The Differences between Abbreviation of English and Chinese Neologisms}

\section{Abbreviating Principles}

The formation of English abbreviation based on abbreviating the meaningless syllable, which means there is just phonetic relation between original words and new words. However, in Chinese, we usually choose morpheme that can represent the main meaning of original word based on the consideration of meaning, which can help us to understand and explain it.

\section{Abbreviating Features}

The relation of English neologisms is not close in form, sound and meaning. There are many examples show that one abbreviation can represent more than one meaning. Such as, CV is not only the abbreviation of curriculum vitae, but also the abbreviation of calorific value. Lu Xiaoming (2003) said that it is very difficult to recover the original meaning according to abbreviation sometimes in English. However, Chinese abbreviation is the unity of form, sound and meaning of each Chinese character, which made the Chinese words stable. So it was not easy to be distorted the meaning. In addition, it's easy to restore the new abbreviations in Chinese words. Usually, according to the sense of a dictionary entry, we can infer the meaning of it in an expression. That means that we can understand the meaning of abbreviation according to explain each character.

\section{CONCLUSION}

According to the contrastive analysis above, we have following findings: There are three main ways of generating of English and Chinese neologisms: creating new words with native word elements (word formation), adding new meanings to existing words and borrowing new words from other language. And there are three main methods of word formation: compounding, affixation and shortening.

The compounding ability of Chinese is strong and the most important way to create Chinese neologisms is compounding. English compounds have a tendency of consisting of more words, and in Chinese there appear more and more polysyllabic neologisms.

Affixation is the tendency of both English and Chinese neologisms. But in quantity, the number of Chinese affix is much less than English. Nevertheless, we must admit that tendency of affixation strengthen the ability of Chinese word formation.

Because of the fast development of scientific technology, a demand which we should use concise and simple words to express complex meaning is needed. Then a lot of abbreviation appeared in both English and Chinese. The formation of English abbreviation based on abbreviating the meaningless syllable. However, in Chinese, we usually choose morpheme that can represent the main meaning of original word based on the consideration of meaning, so they have essential differences, for example: abbreviating principles and abbreviating features.

\section{REFERENCES}

[1] Chenyuan. (2000). Sociolinguistics. Beijing: The Commercial Press.

[2] Chu Xiaoning. (2004). Comparative Study about Motivation of Compounds in English and Chinese. [Master's Thesis]. Qingdao: Institute of Foreign Languages in Ocean University of China.

[3] Fu Huaiqing. (1985). Modern Chinese Vocabulary. Beijing: Peking University Press.

[4] Liu Shuxin. (1990). Description of Chinese Lexicology. Beijing: The Commercial Press.

[5] Lu Xiaoming. (2003). The Recognition of Chinese Words in Terms of the Differences and Similarity in English and Chinese Abbreviations. Foreign Language and Foreign Language Teaching, 2, 17-19.

[6] Lv Shuxiang. (1979). The Questions of Chinese Grammatical Analysis. Beijing: The Commercial Press.

[7] Su Xinchun. (1994). Functionalism of Chinese Words Linguistics. Nanchang: Jiangxi Educational Press.

[8] Shao Zhihong. (1997). Research and Comparative Research of English and Chinese. Shanghai: East China University of Science and Technology Press.

[9] Xu Tongqiang. (1998). Theory of Language. Changchun: Northeast Normal University Press.

[10] Zhang Yongyan. (1982). Theory of Lexicology. Wuhan: Central College of Engineering Press.

[11] Zhang Weiyou. (1997). A Course in English Lexicology. Wuhan: Central China Normal University Press.

[12] Zhou Qiqiang. (2001). The Common Features of Word Formation Devices in Modern English and Chinese. Foreign Language and Foreign Language Teaching, 5, 28-31. 
Shiyun Cheng was born in Shanxi, China in 1992. She is currently a post-graduate student in linguistics in Shanxi Normal University, China.

During the post-graduate, she held the post of English Teacher for public English college students in Shanxi Normal University for one year in 2016. On summer holiday in 2017, she also had a part-time job in a cram school in Linfen, Shanxi province in China. 